\title{
Types and microbial genesis of carbonate microbodies in Zoophycos from the Pennsylvanian to Cisuralian Taiyuan Formation in North China
}

\author{
Hui-Bo Song ${ }^{1,2}$, Xiang-Yu Zhang ${ }^{1}$, Shun-Xi Liu ${ }^{1 *}$, Bin Hu ${ }^{1,3^{*}}$, Rui-Rui Guo ${ }^{4}$ and Yu-Jun Bi ${ }^{1}$
}

\begin{abstract}
Many kinds of ichnofossil Zoophycos occur commonly in the carbonate rocks of Pennsylvanian to Cisuralian Taiyuan Formation in North China. In this study, carbonate microbodies types were identified in four differently-colored fillings of Zoophycos using scanning electron microscopy (SEM) and energy dispersive spectroscopy (EDS). Based on the morphologic characteristics, these carbonate microbodies can be divided into three groups, i.e., spheroids, framboids and rhabditiforms. According to the structural features of surface and individual or aggregate morphologies, the three groups can be further subdivided into thirteen types: (1) smooth spheroids; (2) spheroids with tiny thorns; (3) spheroids with a finely granulated surface; (4) spheroids with a flocculent surface; (5) spheroids with a vermiform surface; (6) framboid monomers; (7) framboid colonies; (8) linear smooth rhabditiform bodies; (9) smooth rhabditiform bodies with expanding ends; (10) biserial rhabditiform bodies; (11) spiral rhabditiform bodies; (12) thorny rhabditiform bodies; and (13) branched rhabditiform bodies. This paper not only describes the morphology, composition and occurrence of the various carbonate microbodies, but also discusses their possible microbial genesis, as follows: (1) carbonate spherical microbodies most likely were generated after globular bacterial cells had been fully displaced by minerals; (2) framboid monomers and colonies corresponding to the morphology of biogenic strawberry (or raspberry) pyrite, with their appearance and internal structure possibly inheriting the morphology of microbial cells, were indirectly generated by some microenvironmental changes due to microbial activity; (3) the morphological features, size, occurrences and preservation of filamentous and rhabditiform microbodies indicate that they may be biogenic structures, and possibly mineralized microbial fossils; and (4) some kind of symbiotic relationship exists between microbial action and the Zoophycos trace-makers. Besides, the differently-colored fillings of Zoophycos are most likely closely related to differences in the composition of microbial taxa, which in turn reflect different microenvironmental conditions.
\end{abstract}

Keywords: Geomicrobiology, Carbonate microbodies, Taiyuan Formation, Trace fossil, Zoophycos, North China

\section{Introduction}

Since the beginning of the twenty-first century, ichnological studies in China has been focused on complex trace fossils (such as Zoophycos, Chondrites, Spirophyton, and Paleodictyon) from the perspective of geobiology (Miller 2003; Miller III 2003; Gong et al. 2009, 2010; Zhang et al. 2015). Based on geobiological features, e.g., pyrite and/or

\footnotetext{
* Correspondence: Isx@hpu.edu.cn; hub@hpu.edu.cn

'School of Resource and Environment, Henan Polytechnic University, Jiaozuo 454000, Henan Province, China

Full list of author information is available at the end of the article
}

iron framboids, in Zoophycos and Rhizocorallium burrows and surrounding rocks, a gardening model was provided and the framboids were generated in the reducing conditions of the microenvironment (Gong et al. 2008; Zhang et al. 2015; Zhang and Zhao 2016).

Zoophycos is a large and complex ichnofossil that commonly occurs in the Phanerozoic marine deposits (Webby 1969; Bottjer et al. 1988; Olivero 2003; Zhang et al. 2015). Some researchers considered that Zoophycos is a kind of commensal structure related to organisms and symbiotic microbes (Bromley 1991; Bromley and Hanken 
2003). Over the last decade, this idea seems to be getting increased attention of many scholars around the world. In addition, a mutualism relationship of trace-makers and microbes in the food chain has been proposed, and the redox conditions have been reconstructed (Gong et al. 2007, 2008, 2010; Hu et al. 2010; Zhang et al. 2015; Zhang et al. 2016).

Geomicrobes are microbes which have special physiological functions and have participated in past and present geological processes (Kuznetsov et al. 1963; Ehrlich and Newman 2009). These microbes include bacteria, archaea and eukaryotes (Burton and Lappin-Scott 2005; Ehrlich and Newman 2009). The microbes with the greatest diversity and abundance may play an important part in understanding the relationship between organisms and environments, such as: (1) methanogens, methaneoxidizing bacteria and archaea, which are related to carbon cycle; (2) sulfur-reducing bacteria and archaea, which are related to sulfur metabolism; (3) anoxygenic phototrophic bacteria and nitrate-reducing bacteria, which are related to iron oxidation; and (4) dissimilatory iron-reducing bacteria, which are related to iron reduction (Gong et al. 2007, 2008; Xie et al. 2012).

Geomicrobial groups and their life processes can influence the behaviors and habits of trace-makers and can also change their environment. For example, some groups of trace-makers may induce a relationship between the food chain, the oxidation-reduction condition and the $\mathrm{pH}$ value (Xie et al. 2011). In contrast, the types, abundances and diversity of geomicrobial groups can be palaeoenvironmental and palaeoecological indicators, which are helpful for explaining the shapes and functions of complex trace fossils.

Here we reported more than ten kinds of carbonate microbes occurring in fillings of Zoophycos, some of which were preserved possibly due to reducing bottom conditions. These data provide new evidence pertaining to the behavior of the Zoophycos organisms, depositional and ecological features, and contribute to the understanding of the relationship between organisms and microbes. In this work, four representative carbonate sections were chosen as study objects: (1) the Xishan section in Taiyuan City of Shanxi Province, (2) the Fucheng section in Jincheng City of Shanxi Province, and (3) the Liuzhuang section in Jiaozuo City of Henan Province, and (4) the Longhuashan section in Yuzhou City of Henan Province. These sections are well-exposed in the western area of North China (Fig. 1).

\section{Geological settings}

The Pennsylvanian to Cisuralian Taiyuan Formation $\left(\mathrm{P}_{1 \mathrm{t}}\right)$ in North China, deposited in an epeiric carbonate platform, including littoral, neritic, lagoonal and tidal flat deposits. It has conformable contacts with both the

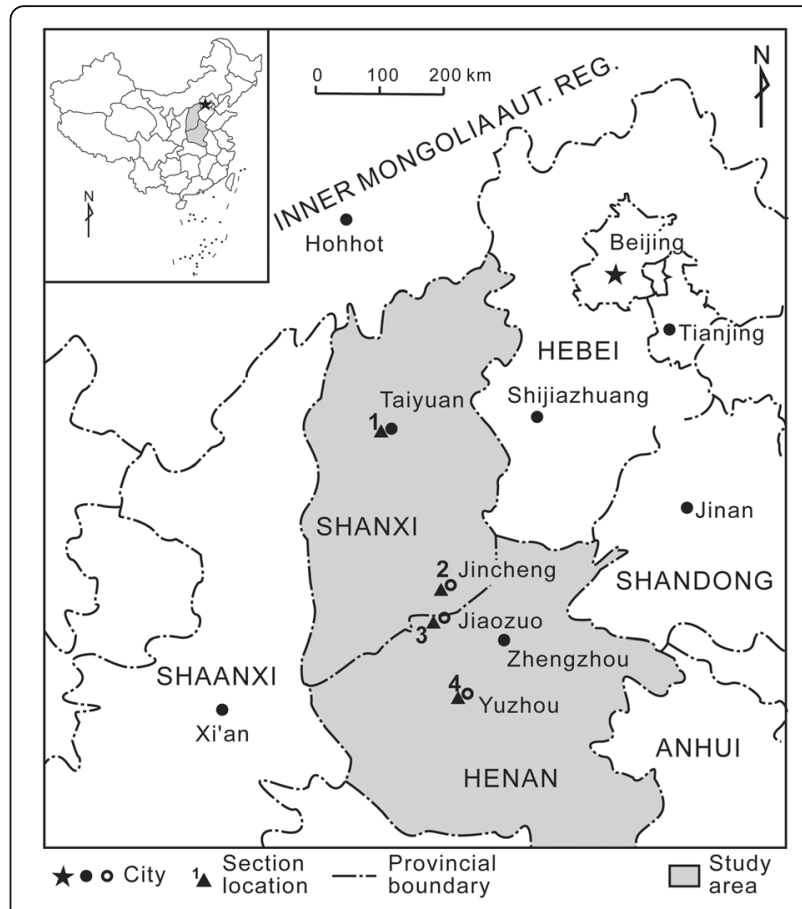

Fig. 1 Map of the study area and section locations. Inset map of China is modified after State Bureau of Surveying and Mapping (No. GS (2016) 1591). 1 =Xishan section; $2=$ Fucheng section; $3=$ Liuzhuang section; $4=$ Longhuashan section

underlying Upper Carboniferous Benxi Formation $\left(\mathrm{C}_{2 \mathrm{~b}}\right)$ and the overlying Middle Permian Shanxi Formation $\left(\mathrm{P}_{2 \mathrm{sh}}\right)$. The Taiyuan Formation $\left(\mathrm{P}_{1 \mathrm{t}}\right), 70-90 \mathrm{~m}$ thick, is mainly composed of thin- to medium-bedded, gray to dark gray bioclastic limestone intercalated with nubby, flaggy or banded chert, claystone, siltstone, sandstone and thin-bedded coal. This unit is generally divided into four members from bottom to top (Fig. 2), namely, the Bottom Siliciclastics Member, the Lower Limestone Member, the Middle Siliciclastics Member and the Upper Limestone Member (Song et al. 2011).

The Bottom Siliciclastics Member consists of thin- to thick-bedded sandstone, siltstone, sandy mudstone, carbonaceous mudstone and thin-bedded coal.

The Lower Limestone Member is marked by shore and shallow marine deposits, containing 2-3 (locally, 4-5) limestone layers that are made up of medium- to thick-bedded dark-gray limestone, bioclastic limestone and micrite, intercalated with thin-bedded sandstone, siltstone, sandy mudstone, mudstone and thin-bedded coal, as well as nubby, flaggy or banded chert.

The Middle Siliciclastics Member is deposited in barrierlagoon systems. It is composed of medium- to thick-bedded, fine- to medium-grained gray-white quartz sandstones, thin-bedded siltstone, sandy mudstone, and two or three layer thin-bedded coal, containing several lenticular bioclastic limestones. 


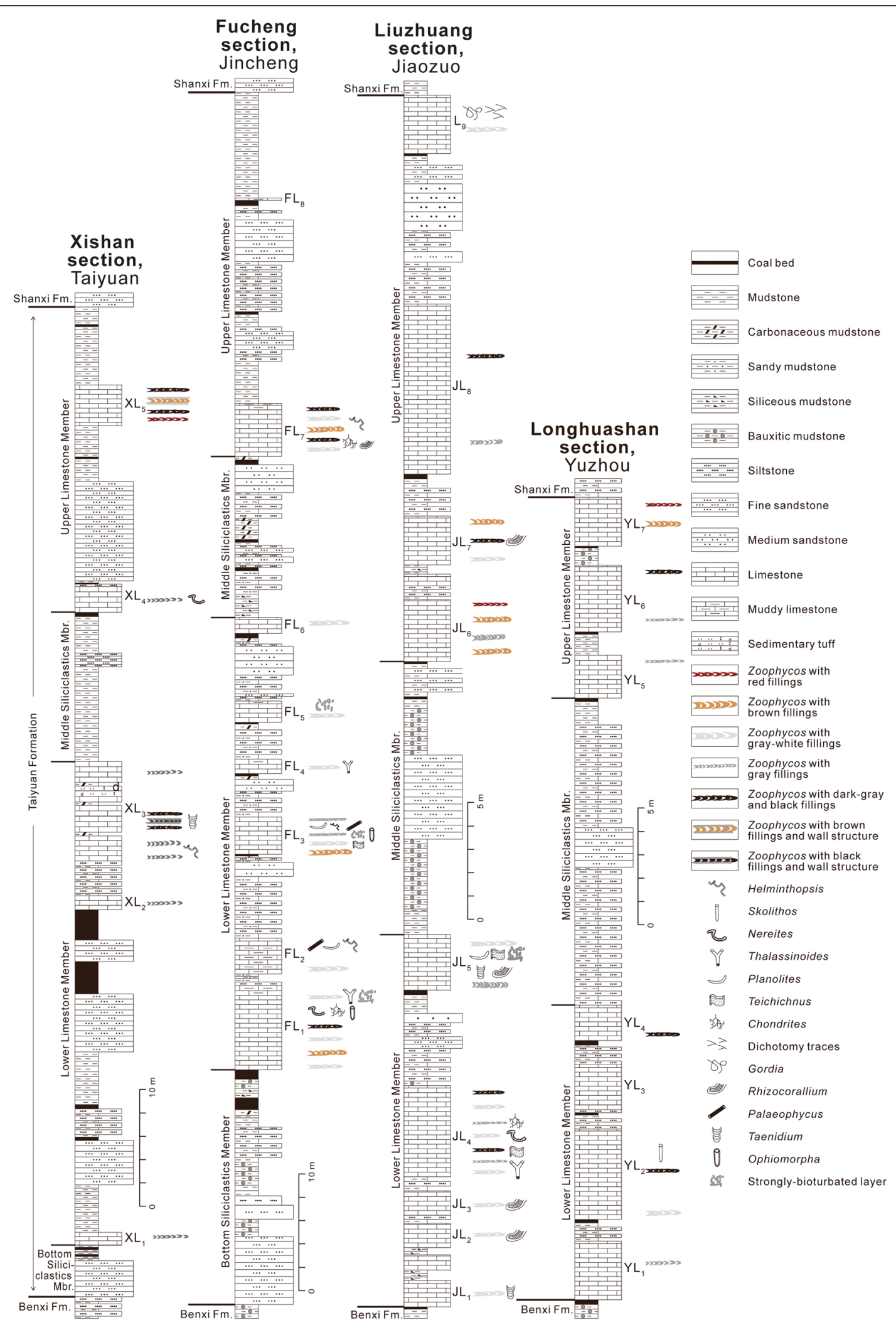

Fig. 2 Lithological sections showing distributional characteristics of ichnofossils in the Pennsylvanian to Cisuralian Taiyuan Formation of North China (from Song et al. 2016). Section positions are shown in Fig. 1. Fm. = Formation; Mbr. = Member 
The Upper Limestone Member is characterized by shallow marine and shore deposits and is composed of four or five layers of gray and dark-gray bioclastic limestones, interbedded with thin-bedded fine sandstone, siltstone, sandy mudstone and thin-bedded coal.

Body fossils such as fusulinids, brachiopods, gastropods, corals and crinoids, are abundant in limestone beds of the Taiyuan Formation. The most abundant ichnofossil is Zoophycos, commonly associated with Chondrites, Gordia, Nereites, Palaeophycus, Planolites, Rhizocorallium, Taenidium, Teichichnus and Thalassinoides ( $\mathrm{Hu}$ et al. 2010). Four types of ichnofabrics were identified based on differences in trace fossil composition, occurrence, abundance and diversity, especially the size and depth of Zoophycos, intensity of bioturbation and color of Zoophycos fillings, combined with the lithologic characteristics of the host rock. The four ichnofabric types are epigenic tiering, shallow tiering, medium tiering and deep tiering ichnofabric (Song et al. 2012, 2016). According to ichnofacies and lithofacies analysis, the depositional environments of the Taiyuan Formation in the studied sections evolved as follows: lagoon and tidal flat $\rightarrow$ littoral and neritic $\rightarrow$ lagoon and tidal flat $\rightarrow$ littoral and neritic $\rightarrow$ tidal flat or delta. At every stage, terrigenous siliciclastic deposits are intermittently mixed. Generally, the carbonate rocks of the Taiyuan Formation formed in a gently-sloping carbonate platform depositional setting (Song et al. 2011, 2016).

\section{Methods and data}

The Zoophycos exhibits four differently-colored fillings, namely, brown, gray-white, gray, and black (Fig. 3). During sampling, a clear flat cross-section of Zoophycos was chosen for observation, and the size of specimens was determined. On the average, each sample was $3 \mathrm{~mm}$ thick, $6 \mathrm{~mm}$ wide, and $9 \mathrm{~mm}$ long, and the observed surface area was about $0.5 \mathrm{~cm}^{2}$. Next, a line was carved with a small knife, along the boundary between the filling and the surrounding matrix, for observation and control of orientation. During the sample processing, first specimens were cleaned with distilled water and dried in a drying box, then the samples were fixed on holders with conducting resin. Finally, all the samples were coated with gold in the ion sputtering apparatus. After specimen preparation, a scanning electron microscope (SEM), model JSM-6390/ LV and EVO MA15, was used to observe the micromorphology of the specimens. Energy dispersive spectroscope (EDS) connected with SEM, model INCA-ENERGY 250, was applied to test the chemical composition.

\section{Types of carbonate microbodies}

Based on detailed SEM observations, different types of carbonate microbodies were found in Zoophycos fillings characterized by four different colors. Microscopic analysis and testing by means of EDS demonstrate that $\mathrm{CaCO}_{3}$ is

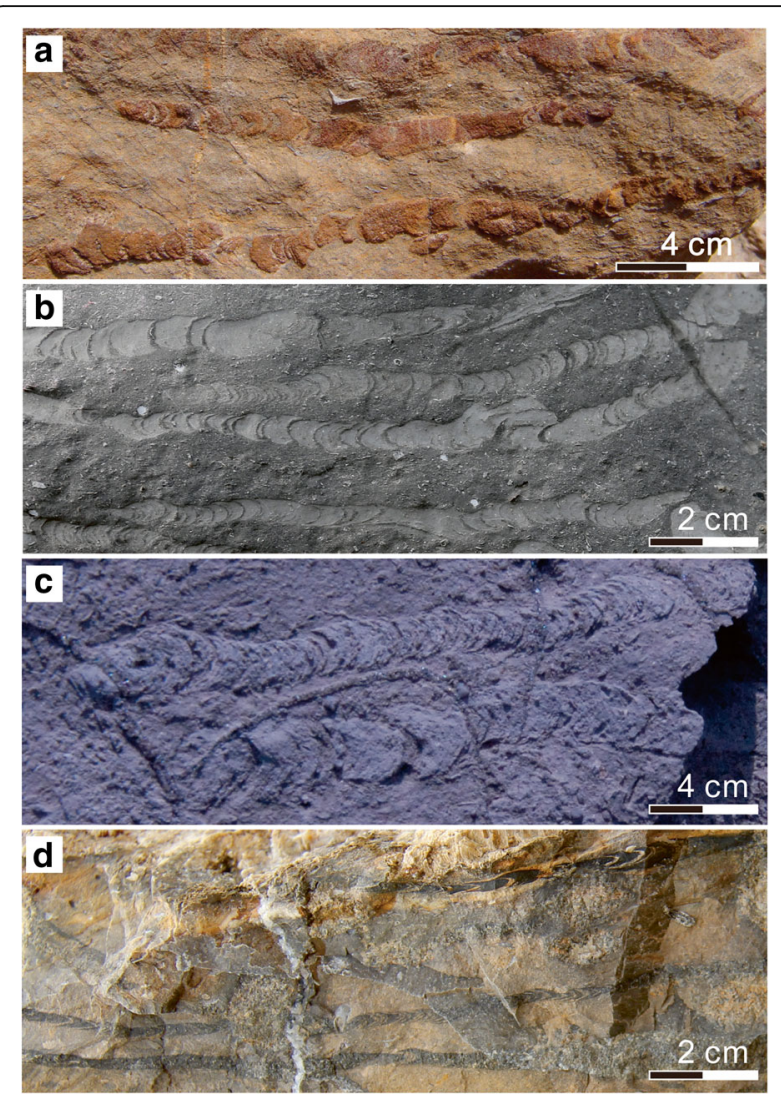

Fig. 3 Four types of differently-colored fillings in Zoophycos from the Pennsylvanian to Cisuralian Taiyuan Formation of North China. a Brown filling; b Gray-white filling; c Gray filling; d Black filling

the main component of the microbodies, and other elements presented are $\mathrm{Fe}, \mathrm{Si}, \mathrm{Mn}$ or $\mathrm{S}$, whose contents vary among the differently-colored fillings. Furthermore, carbonate microbodies are more abundant in brown (or red) and black fillings than in gray and gray-white fillings.

According to their morphology, the carbonate microbodies found in the fillings of Zoophycos can be divided into three groups: spheroids, framboids and rhabditiforms.

\subsection{Spheroid microbodies}

On the basis of different surface structures, the carbonate spheroids can be further divided into five types as follows: type 1: smooth spheroids; type 2: spheroids with tiny thorns; type 3: spheroids with a finely granulated surface; type 4: spheroids with a flocculent surface; and type 5: spheroids with a vermiform surface.

\subsubsection{Type 1: Smooth spheroids (Fig. 4a-c)}

These spheroids are well-preserved, with a relatively smooth surface, and their diameters range from $2 \mu \mathrm{m}$ to $15 \mu \mathrm{m}$. The single spheroids are flattened (Fig. 4b, c), $29 \mu \mathrm{m}$ in length and $21 \mu \mathrm{m}$ in width. The surface of some spheroids exhibits a gap. The main elements of the 

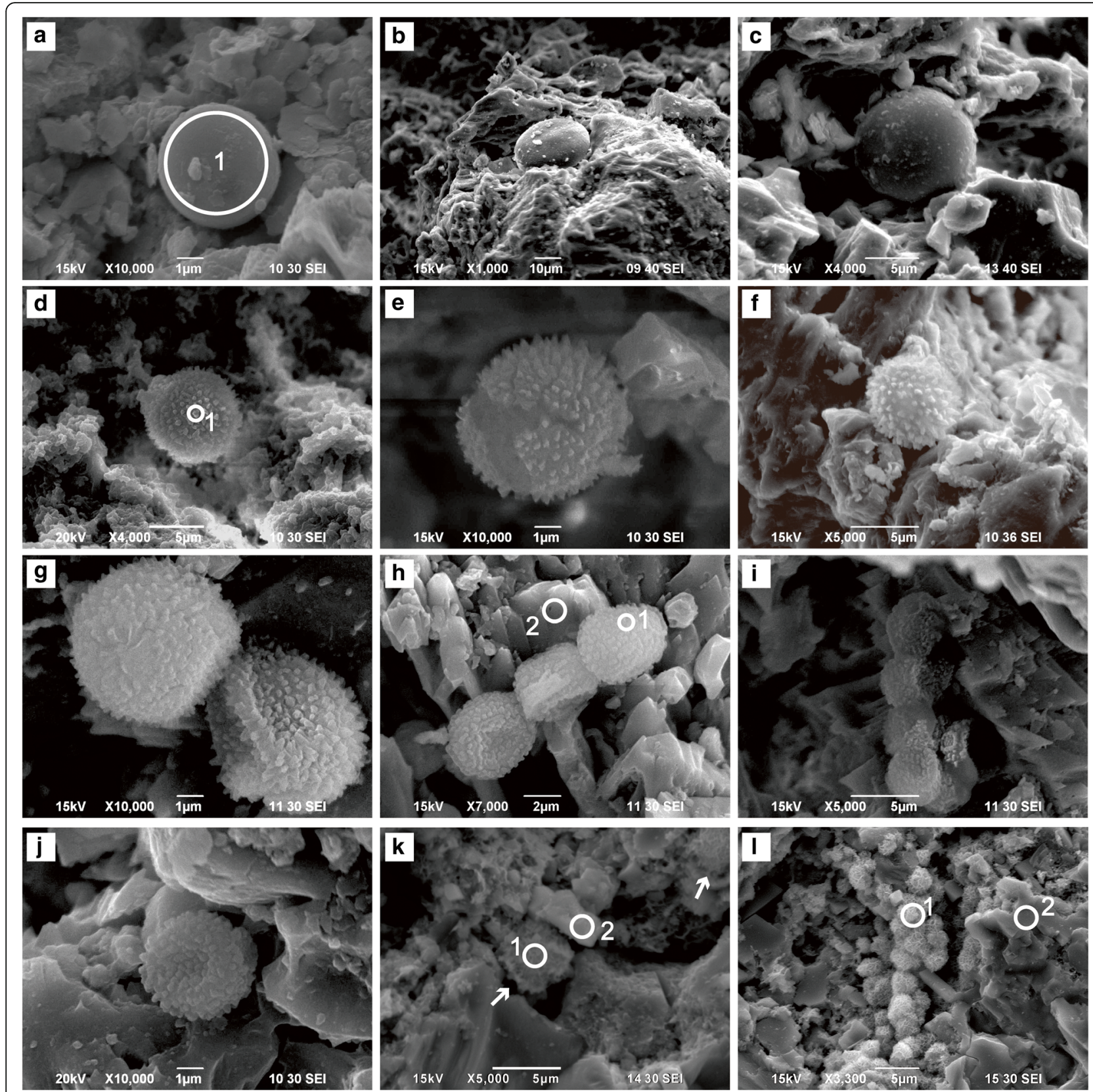

Fig. 4 Carbonate spheroids found in the Zoophycos fillings from the Pennsylvanian to Cisuralian Taiyuan Formation of North China. Testing points of elements using EDS on spheroids and on smooth calcite crystals are marked out with numbers 1 and 2, respectively. Sampling localities are shown in Fig. 2 a-c Smooth spheroids, with (a) from $J_{L_{7}}$ and (b) and (c) from $\mathrm{FL}_{1}$; $\mathbf{d}$-f Spheroids with tiny thorns, with (d) from $J_{4},(\mathbf{e})$ from $J_{8}$, and (f) from $\mathrm{FL}_{7} ; \mathbf{g}-\mathbf{j}$ Spheroids with a finely granulated surface, with $(\mathbf{g})$ to (i) from $\mathrm{J}_{4}$, and (j) from $\mathrm{JL}_{2} ; \mathbf{k}$ Spheroids with a flocculent surface (white arrows), from $\mathrm{FL}_{3} ; \mathbf{I}$ Spheroids with a vermiform surface, from $\mathrm{FL}_{3}$

spheroid surface (Fig. 4a, point 1 ) are $\mathrm{C}, \mathrm{O}$ and $\mathrm{Si}$, with some $\mathrm{Ca}, \mathrm{Al}$, and $\mathrm{Fe}$.

\subsubsection{Type 2: Spheroids with tiny thorns (Fig. $4 d-f$ )}

These spheroids, 6-9 $\mu \mathrm{m}$ in diameter, are characterized by regularly-distributed tiny thorns covering the surface. The main elements of the grains (Fig. $4 \mathrm{~d}$, point 1 ) are $\mathrm{C}$, $\mathrm{Ca}, \mathrm{O}$, and $\mathrm{Si}$, and the minor elements are $\mathrm{S}, \mathrm{Cl}, \mathrm{K}, \mathrm{Al}$ and Na. A small fissure $(0.1-2 \mu \mathrm{m}$ in width) occurs locally on the surface displaying a smooth inner surface (Fig. 4e).

\subsubsection{Type 3: Spheroids with a finely granulated surface (Fig. $4 g-j$ )}

These spheroids, $2-10 \mu \mathrm{m}$ in diameter, are marked by a dense finely granulated surface. The fine granules are 
regularly arranged, but their shapes are irregular. Particularly, some spheroids touch each other and are arranged as a coenobium, involving two (Fig. 4g), three (Fig. 4h), or even four spheroids (Fig. 4i) linked together. Some spheroids have two relatively concave sides (Fig. 4h, i). The EDS analysis shows that the main elements of the spheroids and their surrounding rocks are $\mathrm{C}, \mathrm{Ca}, \mathrm{O}$, and $\mathrm{Si}$, but the specific elements on the surface of spheroids are $\mathrm{S}, \mathrm{Cl}$ and $\mathrm{K}$.

\subsubsection{Type 4: Spheroids with a flocculent surface (Fig. 4k)}

These spheroids are characterized by a complex flocculent surface; the surrounding matrix is composed of large, smooth calcite crystals (Fig. $4 \mathrm{k}$, point 2 ). The elements of the spheroid are more complex and are commonly $\mathrm{C}, \mathrm{O}$, and $\mathrm{Ca}$, and small amounts of $\mathrm{Fe}, \mathrm{Mn}$, and $\mathrm{S}$ (Fig. 4k, point 1 ). In appearance, this spheroid is similar to extracellular polymeric substances (EPS), nannofossils of sulfur bacteria, or analogous pyrite spheroids (Gong et al. 2008).

\subsubsection{Type 5: Spheroids with a vermiform surface (Fig. 4l)}

The spheroids, $2-3 \mu \mathrm{m}$ in diameter, have a worm-like surface structure and form groups of about 30 closelylinked monomers (Fig. 4l). The spheroids are embedded in coarse-grained, smooth calcite crystals (Fig. 4l, point 2). The compositional elements of the spheroid surface (Fig. 4l, point 1) are $\mathrm{O}, \mathrm{Fe}, \mathrm{C}, \mathrm{Ca}, \mathrm{Mn}$, and $\mathrm{S}$, in which the main elements are $\mathrm{O}$ and $\mathrm{Fe}$, with weight percentages of $61.64 \%$ and $14.42 \%$, respectively.

\subsection{Framboid microbodies}

Based on the aggregation of tiny spheroids, the framboids found in the fillings of Zoophycos can be further divided into two types: type 1-framboid monomers, and type 2-framboid colonies.

\subsubsection{Type 1: Framboid monomers (Fig. 5a-f)}

Framboid monomers, commonly 3.5-7.5 $\mu \mathrm{m}$ in diameter, are an aggregate of tiny spheroids that exhibit many micrograins on the surface (Fig. 5a, b), embedded sporadically within calcite crystals or in the gap between two adjacent calcite crystals. The micrograins are distributed on the surface or inside the monomer densely and evenly. They also may display a flower-like arrangement. Six different kinds of framboids have been observed: (1) Three framboid monomers (3.5-7.5 $\mu \mathrm{m}$ in diameter) appear grouped (Fig. 5a), and their surfaces show numerous micrograins, $0.5-1 \mu \mathrm{m}$ in diameter. The main elements of the micrograins are $\mathrm{Fe}$ and $\mathrm{O}$, with weight percentages of $58.26 \%$ and $33.45 \%$, respectively. Minor elements include C, $\mathrm{Si}$, and $\mathrm{Ca}$. (2) Framboid monomers $(4.5 \mu \mathrm{m}$ in diameter) are marked by many regular triangular and quadrilateral micrograins with edge-lengths of $0.4-0.5 \mu \mathrm{m}$ (Fig. 5b). (3)
Framboid monomers $(7.5 \mu \mathrm{m}$ in diameter) with about 70 closely adjacent micrograins $(1 \mu \mathrm{m}$ in diameter, Fig. $5 \mathrm{c})$. (4) Framboid monomers $(5.5 \mu \mathrm{m}$ in diameter $)$ preserved on the concave surface of calcite crystals and with micrograins, $0.5-0.75 \mu \mathrm{m}$ in diameter (Fig. 5d). (5) Framboid monomers (5 $\mu \mathrm{m}$ in diameter) display many hexagonal micrograins, $0.65 \mu \mathrm{m}$ in diameter; five adjoining monomers are closely squeezed to each other, showing concave pits after removal of the framboid monomers (Fig. 5e). (6) Framboid monomers $(12 \mu \mathrm{m}$ in diameter) embedded in Si-rich calcite crystals; the main elements of the micrograins (about $0.8 \mu \mathrm{m}$ in diameter) are $\mathrm{O}, \mathrm{Fe}$, and $\mathrm{C}$, along with a few minor elements $(\mathrm{Ca}, \mathrm{Si}, \mathrm{Al})$ based on the SEM and EDS analyses (Fig. 5f, points 1,2). These characteristics seem to indicate that there is a positive correlation, in diameter change, between the framboid monomers and their micrograins. This may suggest that the genesis of framboid monomers is related to microbial action.

\subsubsection{Type 2: Framboid colonies}

The framboid colonies (Fig. 5g-l) identified in three samples are characterized by adjoining of many micrograins or microspherules and are similar to the pyrite framboids found in light-gray spreiten of Zoophycos. They are interpreted as microbial colonies (Gong et al. 2007, 2008).

In sample 1 (Fig. 5 g), the framboid colony, appearing inside calcite crystals, is about $12 \mu \mathrm{m}$ in width and $15 \mu \mathrm{m}$ in length, and includes nearly 200 closely-gathered microspherules (single, about $0.8 \mu \mathrm{m}$ in diameter).

In sample 2 (Fig. 5h), the framboid colony is more than $10 \mu \mathrm{m}$ in diameter and consists of many microspherules, along with some residual pits observed on the framboid colony surface.

In sample 3 (Fig. 5i), the framboid colony is about $40 \mu \mathrm{m}$ in width and $50 \mu \mathrm{m}$ in length, with more microspherules than in the previous two samples, and shows many concave pits which are the sites of former microspherules. The EDS-data show that the main elements of the microspherules are $\mathrm{Fe}$ and $\mathrm{O}$, with weight percentages of $61.07 \%$ and $30.13 \%$, respectively. A higher value of $\mathrm{Fe}$ is present in the area of framboid colony, and other minor elements include $\mathrm{C}, \mathrm{Ca}, \mathrm{O}, \mathrm{Si}$ and $\mathrm{Al}$.

In sample 4 (Fig. 5j), many framboid monomers (more than $5 \mu \mathrm{m}$ in diameter) with an uneven surface adjoin, and are embedded or wrapped in calcite crystals, with $\mathrm{O}$ and $\mathrm{Fe}$ as main elements.

In sample 5 (Fig. $5 \mathrm{k}, \mathrm{l}$ ), larger framboid colonies are visible. In the enlarged view (Fig. 5l), the cauliflower-like framboid colony (about $17.3 \times 14.7 \mu \mathrm{m}^{2}$ ) consists of numerous micrograins that cover the surrounding calcite crystals. These micrograins, about $1.33 \mu \mathrm{m}$ in diameter, are evenly distributed and regularly arranged. The EDS 

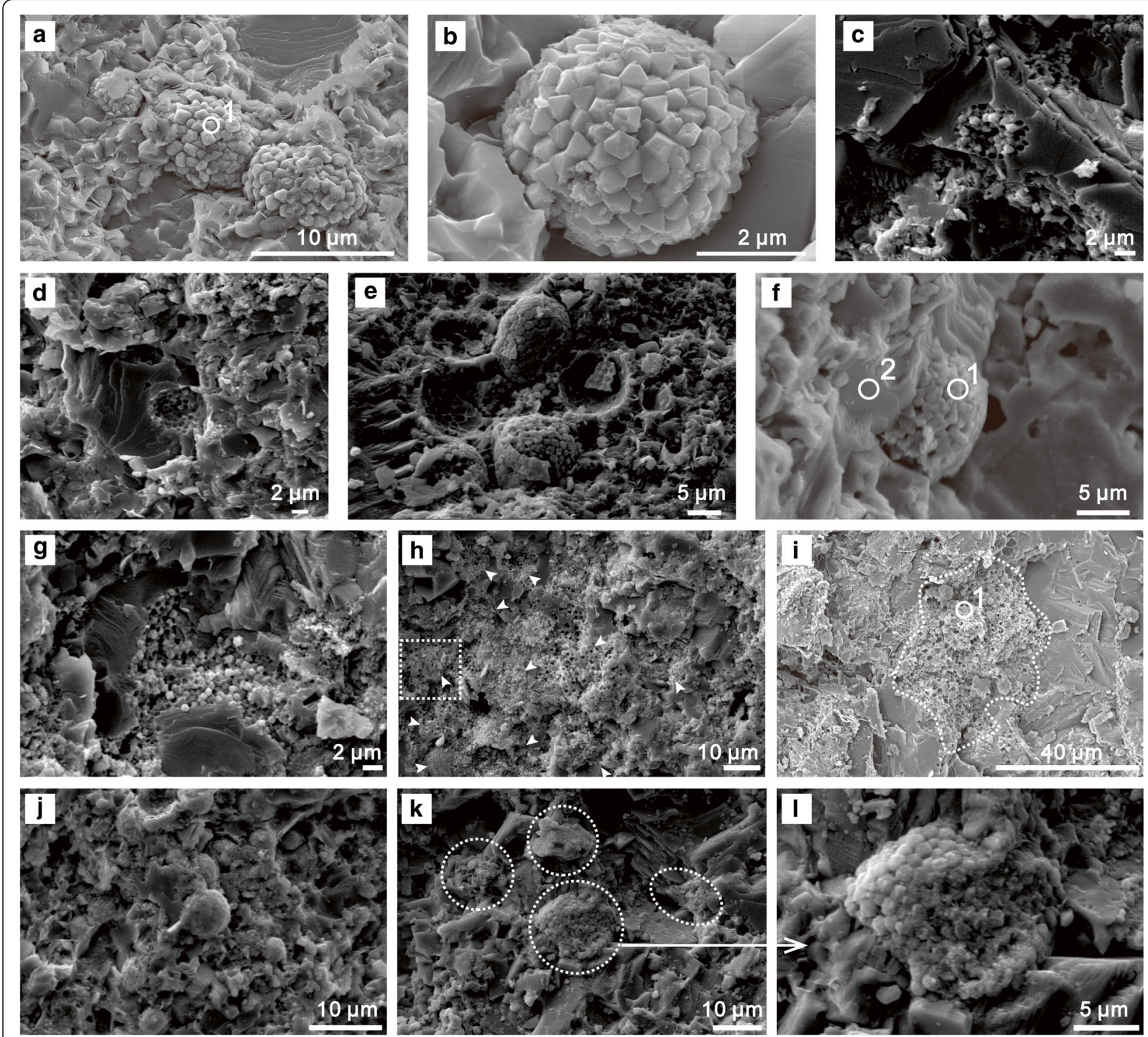

Fig. 5 Framboid monomers and colonies found in the fillings of Zoophycos from the Pennsylvanian to Cisuralian Taiyuan Formation of North China. Testing points of elements using EDS on framboids and on calcite crystals are marked out with numbers 1 and 2, respectively. Sampling localities are shown in Fig. 2. a-f Framboid monomers, with (a) to (e) from $\mathrm{XL}_{5}$, and (f) from $\mathrm{FL}_{1} ; \mathbf{g}-\mathbf{I}$ Framboid colonies (arrows and dashed circles), with (g) to (h) from $Y L_{7}$, (i) from $J_{6}$, (j) from $\mathrm{FL}_{2}$, and (k) to (I) from $\mathrm{YL}_{2}$. I Is an enlarged view of one framboid colony in (k)

data show that the main elements of the micrograin surface are $\mathrm{Fe}$ and $\mathrm{O}$, with other minor elements $(\mathrm{C}$, $\mathrm{Ca}$, and $\mathrm{Si}$ ).

\subsection{Rhabditiform microbodies}

Based on surface features and shapes, rhabditiform microbodies can be further divided into six types as follows: type 1: linear smooth rhabditiform bodies; type 2: smooth rhabditiform bodies with expanding ends; type 3: biserial rhabditiform bodies; type 4: spiral rhabditiform bodies; type 5 : thorny rhabditiform bodies; and type 6 : branched rhabditiform microbodies.

\subsubsection{Type 1: Linear smooth rhabditiform bodies (Fig. 6a)}

These rhabditiform bodies are about $20 \mu \mathrm{m}$ long and about $1 \mu \mathrm{m}$ in diameter, appearing as a straight line with a smooth surface and round cross-section. It occurs dispersed in the black fillings of Zoophycos.

\subsubsection{Type 2: Smooth rhabditiform bodies with expanding ends (Fig. 6b)}

This rhabditiform body, $15.38 \mu \mathrm{m}$ in visible length and $0.77 \mu \mathrm{m}$ in width, also forms a straight line and has a smooth surface. In addition, it has an expanding end 

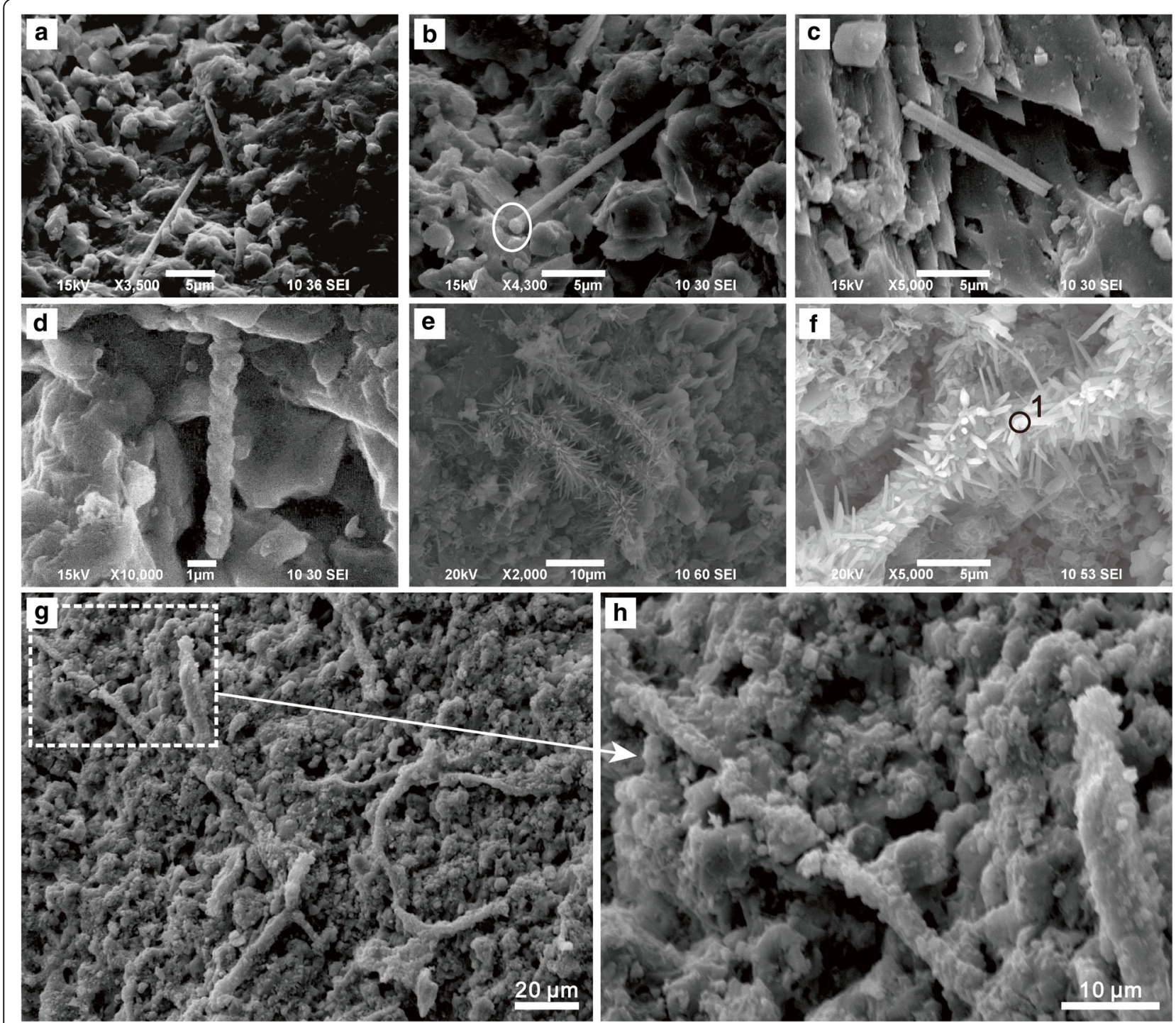

Fig. 6 Rhabditiform microbodies found in the fillings of Zoophycos from the Pennsylvanian to Cisuralian Taiyuan Formation. a Linear smooth rhabditiform bodies, from $\mathrm{FL}_{7}$; $\mathbf{b}$ Smooth rhabditiform bodies with expanding ends (white oval), from $\mathrm{FL}_{7}$; $\mathbf{c}$ Biserial rhabditiform bodies, from JL $\mathrm{L}_{4}$ d $\mathrm{d}$ Spiral rhabditiform bodies, from $\mathrm{FL}_{7} ; \mathbf{e}-\mathbf{f}$ Thorny rhabditiform bodies, from $\mathrm{J}_{7} ; \mathbf{g}-\mathbf{h}$ Branched rhabditiform microbodies, from $\mathrm{FL}_{3}$. $\mathbf{h}$ is an enlarged view of ( $\mathbf{g}$ )

that is about $1.15 \mu \mathrm{m}$ in diameter. It occurs dispersed in the black fillings of Zoophycos.

\subsubsection{Type 3: Biserial rhabditiform bodies (Fig. 6c)}

The rhabditiform body forms a biserial straight line and is smooth. Its length is $10 \mu \mathrm{m}$ and its single-row diameter is $0.4 \mu \mathrm{m}$. It is preserved in the gap between calcite crystals in the black fillings of Zoophycos.

\subsubsection{Type 4: Spiral rhabditiform bodies (Fig. 6d)}

This rhabditiform body is $9 \mu \mathrm{m}$ in length and about $1 \mu \mathrm{m}$ in diameter, and has the shape of a inverted "L-shaped spiral". It occurs in the gap between calcite crystals in the black fillings of Zoophycos.
4.3.5 Type 5: Thorny rhabditiform bodies (Fig. 6e, f)

The prominent features of these rhabditiform bodies are a straight course and dense needle-like thorns on the surface. The main elements of the thorns (Fig. 6f, point 1) are $\mathrm{O}, \mathrm{C}, \mathrm{Ca}, \mathrm{Mn}, \mathrm{Fe}, \mathrm{Si}$ and $\mathrm{S}$. The weight percentages of $\mathrm{Mn}$ and $\mathrm{Fe}$ are $17.75 \%$ and $6.87 \%$, respectively; Si and S are minor elements. As shown in Fig. 6e, three rhabditiforms bodies are preserved together and arranged parallel to each other, with a visible length of $50 \mu \mathrm{m}$ and a diameter of $1.5 \mu \mathrm{m}$. The thorns on the surface are 5-7 $\mu \mathrm{m}$ in length and less than $1 \mu \mathrm{m}$ in diameter.

4.3.6 Type 6: Branched rhabditiform microbodies (Fig. $6 g, h$ ) These microbodies have a branched rhabditiform shape (about $4.0 \mu \mathrm{m}$ in diameter) (Fig. $6 \mathrm{~g}$ ). The enlarged view 
(Fig. 6h) shows a granular surface. The microscopic analysis revealed their chemical composition of $\mathrm{CaCO}_{3}$.

\section{Discussion}

It is important to examine the geneses of above-described types of carbonate microbodies in the Zoophycos burrows, whether they are biogenic or inorganic, synsedimentary or diagenetic. According to Southam and Donald (1999), Westall et al. (2001) and Teng et al. (2006), carbonate microbodies found in Zoophycos may be interpreted as having a microbial origin and are likely microbial fossils. This view is supported by the following three reasons:

First, the microbodies are primary and preserved in-situ. It was made sure that the samples used for analysis were not contaminated by new microorganisms (Westall and Folk 2003). Careful observation of all samples shows that these microbodies are closely integrated with their surrounding matrix; some were embedded in holes and cracks of the host rock, while others were interbedded with their surrounding rocks. These microbodies are extremely small and well-preserved, and exhibit certain microbial morphologies and growth characteristics such as curving, branching, links, and cracked spheres. This suggests that they were not transported after formation but rather grew in-situ. The above-mentioned characteristics are consistent with in-situ preservation of burrows.

Second, on one hand, some microorganisms can transform the microenvironment around them by their own metabolism; on the other hand, these organisms and secreted extracellular polymeric substances can serve as nucleation sites for crystal nuclei, providing favourable conditions for the growth of corresponding mineral crystals.

It has been found in nature and in laboratory simulations that calcium carbonate nucleation and growth on the surface of microbial organisms may eventually result in special shapes such as spheres and dumbbells (Teng et al. 2006). Under these circumstances, it is probable that geomicrobial cells are mineralized in-situ and are preserved quickly, and the form and function of cells can adjust and control the shape and size of microbial fossils, generating spherical, rod-shaped, helical, and filamentous shapes (Southam and Donald 1999). The individual size and shape, fine structure, aggregating habits, occurrence, and other aspects are consistent with the original organisms (i.e., the organisms before mineralization) after some bacteria are displaced by minerals (Westall et al. 2001). In addition, Zhang et al. (2011) studied some microbody types (such as small-ball, rubber-hose-like, tubular and cystiform) in stromatolites, and deduced based on the simple structures that a microbial community developed in the stromatolites, formed in a manner similar to modern cyanobacteria with a size in the order of a micron, and suggested that cyanobacteria dominated the community. So, the characteristics of the carbonate microbodies found in Zoophycos, such as specific shapes, minute size, complex surface structures, monomer aggregation and biofilm, can also be used as a basis for deducing their microbial origin.

Third, SEM and EDS analyses show that the surrounding rock is mainly composed of $\mathrm{CaCO}_{3}$, and the surface of carbonate microbodies consists of many kinds of elements besides those found in $\mathrm{CaCO}_{3}$. Furthermore, the elements discovered in different types of microbodies were not all the same.

The study of microorganisms near hydrothermal vents in the Pacific Ocean demonstrates that the surfaces of almost all the extracellular polymers and mineralized bacteria are wrapped by irregular silicon-rich manganese oxide, iron oxide and iron silicate minerals (Juniper and Fouquet 1988).

Also in previous reports, the elements in microbial fossils from hydrothermal plume fluids of the mid-ridge in the Southwest Indian Ocean were tested by EDS and high values were recorded for the elements $\mathrm{Si}, \mathrm{O}, \mathrm{Ca}, \mathrm{Fe}$, and $\mathrm{Zn} . \mathrm{Ba}$ is shown to be abundant in spheroids, while $\mathrm{Ti}$ and $\mathrm{Mn}$ appear to be abundant in filamentous microbial fossils. From these reports, it can be inferred that the main mechanisms of microbial petrification in the plume fluids are calcification and iron silicification (Lei et al. 2009).

The various microbodies found in the course of this study contain different elements and elemental abundances at their surface, which are related to the selective absorption of different elements during the petrification process. Apparently, different types of microorganisms can absorb different kinds of elements, and different metabolic processes may produce different microenvironments and further cause the dissolution, migration and precipitation of different minerals.

\subsection{Origin of the spherical carbonate microbodies}

Spherical carbonate microbodies contain important information of the microscopic and macroscopic world. Biogenic microsphere particles, $1-500 \mu \mathrm{m}$ in diameter, may be distinguished by characteristics such as an umbilical-cord-like structure, organic content, and algal residue. Apparently, the microbial population plays an important role in the formation of spherical carbonate minerals (Xie et al. 2012). Previous investigations which provided some examples supporting this hypothesis are described below:

1) Some coccoid and spiral-shaped bacterial microfossils $(0.4-3.0 \mu \mathrm{m}$ in diameter) were found in the lamellae of Zoophycos from limestones of the Permian Maokou Formation in southern China. Using 
molecular fossil detection, a reduced state of sulfur was found in the sediments, indicating reducing conditions, which showed that the formation of these microbial fossils is associated with sulphate-reducing bacteria (Gong et al. 2007).

2) A large number of spherical carbonate aggregates were found in carbonates of a cold spring, located in the northern part of the South China Sea. Magnified, the sphere surfaces exhibit worm-like and filamentous structures (similar to Fig. 4l), which are all microbial structures (Yang et al. 2009).

3) Some spherical (or walnut-shaped) microbial fossils found in hydrothermal plume fluids may reflect spherical bacterial cells which were completely replaced by minerals (Westall and Folk 2003).

4) Microbial spherical structures, the size of a micron, were found well preserved in dark layers of Neogene stromatolites of the Qaidam Basin of northwestern China. Through microscopic observation and analysis, it was concluded that these spheres may be some sulphate-reducing microorganisms similar to coccoid microbes. Meanwhile, some submicron-scale spherical particles were found, which may be the products of microorganism syneresis under extreme conditions, and were an important component of extracellular polymeric substances in the stromatolite and microbial mats (Wen et al. 2010).

In addition, simulation experiments have repeatedly confirmed that some spherical carbonate minerals can be synthesized by the action of microorganisms (Wen et al. 2010). For example, spherical carbonates have been synthesized by the interaction between minerals and desulfovibrio under experimental conditions at room temperature and hypoxia. In addition, extracellular polymeric substances (EPS) secreted by bacteria play an important role in the mineralization process (Bontognali et al. 2008). By tracking the formation process of globular carbonate rocks by the action of Citrobacter freundii, it has been found that mineral aggregates developed some transitional forms such as cauliflower-shaped and dumbbellshaped particles before turning into the globular structure (Ma et al. 2009).

The results of this study suggest that the genesis of spherical carbonate microbodies (such as some smooth spheroids) is similar to the above-mentioned situation, but some new types have also been found. Morphologically, they are most likely generated after the globular bacterial cells have been displaced fully by minerals or are related to their displacement processes.

At first sight, framboids, just as strawberry-shaped pyrite, were formed near the redox interface, and can be used to explain changes in the host environment. Generally, a statistical analysis of pyrite particle size can be used to explain the redox conditions. However, a pre-condition is that the pyrite grew only in the early hypoxic diagenetic environment and the subsequent sedimentary environment did not change. In addition, factors influencing the particle size of pyrite also include storm events, changes in the sedimentation rate, and mineral recrystallization.

It is generally acknowledged that strawberry-shaped pyrite is transformed by intermediate state of iron sulfide, but there are also several other theories on their genesis, such as "biogenic", "inorganic" and "multiple reasons" (Xie et al. 2012). The number of microcrystals in strawberryshaped pyrite of microbial origin is usually only 10 to 100 particles, and their microcrystalline surface is clean while their organic substances may be encased. In contrast, the number of non-biogenic microcrystals may be as high as $10^{9}$, and the microcrystal surface exhibit numerous microstructures, whereby the organic substances should be not encased (Popa et al. 2004; Folk 2005).

The framboid monomers and framboid colonies found in this study correspond to the morphological features of biogenic strawberry pyrite. The special appearance and internal structure of the framboids may have inherited the morphology of microbial cells, which are indirectly generated by some microenvironmental changes because of the influence of microbial activity.

EDS data indicate that $\mathrm{Fe}$ and $\mathrm{O}$ contents are higher on the microcrystal surface, but $\mathrm{S}$ is hardly detected in the samples, which was most likely oxidized at a later stage. Of course, the genesis of microcrystals can be explained more accurately based on the microelement abundances and isotopic characteristics.

\subsection{Genesis of the rhabditiform carbonate microbodies}

As previously mentioned, this study includes the findings of various rhabditiform microbodies that show the following features: (1) The same types of rhabditiform microbodies have a consistent diameter; (2) their cross-section is circular or elliptical; (3) these microbodies have a linear, curved, branched and winding morphology, and (4) they are commonly preserved together in a community that is manifested by many types of miscellaneous members and symbionts. These features suggest that the filamentous and rhabditiform microbodies are biogenic structures, and even microbial fossils, that underwent mineralization.

Also, there are structural features of microbes in the microbodies, typically including the obvious surface diaphragm, the spherical end (Fig. 6b), and the tubular structure (pore size of 1.1-1.5 $\mu \mathrm{m}$ ) (Banfield et al. 2000). The formation of smooth rhabditiform microbodies (Fig. 6a-c) may be due to the replacement of microbes by minerals, while the formation of rhabditiform bodies with irregular granular surfaces may be due to microbes that absorbed some elements from their environment. In addition, some rhabditiform bodies with some portion 
strumae on the surfaces may be caused by silification of the outer wall.

Chen et al. (2007) simulated microbial silicification in the natural environment. They found that the bacteria can be quickly silicified, so that their shapes can be well preserved. At the same time, the deposits of some siliceous fine particles on surface can be divided into two distinct layers, in which the compact and regular inner layer preserves the bacterial surface structure, but the outer layer only holds the outline of the bacterial shape.

According to morphological taxonomy, rhabditiform bacteria should be classified as sulphur- and metal-oxidizing bacteria, which can promote mineral crystallization and aggregation (Westall and Folk 2003). Based on size, shape, cell division, and other physical features, four types of filaments have been identified in the Black Smoker samples from the Okinawa Trough, and it has been speculated that these filaments may be some fungi and chemoautotrophic bacteria formed by sulfur or iron oxidation (Feng et al. 2006).

Ghiorse (1984) suggested that rhabditiform bacteria with branches containing higher values of $\mathrm{Fe}$ and $\mathrm{Mn}$ may be preferred sites of ferromanganese settlement. In addition, the present study considers that some rhabditiform microbodies with granular, needle-like and cluster structures on the surfaces (Fig. 6e-i) may be the result of bacterial oxidation of mineral surfaces. These structure features on the surfaces imply that rhabditiform bacteria were preserved because of their rapid mineralization.

The trace maker of Zoophycos very likely cultivated various types of chemoautotrophic microbial flora in its burrows and formed with them a symbiotic relationship.

This study also found that various carbonate microbodies are quite abundant in the brown (red) and black burrow fillings, but in the gray-white and gray fillings fewer microbody types occur. Thus, it can be speculated that the formation of differently-colored fillings of Zoophycos is closely related to the differences in microbial taxa reflecting different ecological conditions. Although types of microbes cannot be determined from the observed microbodies, it is possible that some kind of symbiotic relationship exists between microbial activity and the trace makers of Zoophycos.

\section{Conclusions}

The trace fossil Zoophycos occurs abundantly in carbonate rocks of the Pennsylvanian to Cisuralian Taiyuan Formation of North China. Various carbonate microbodies were found in the four differently-colored fillings of Zoophycos on the basis of observation and analyses by SEM and determination by EDS.
According to the morphological characteristics, these carbonate microbodies can be divided into three groupsnamely spheroids, framboids and rhabditiform bodies. Based on different surface features, these carbonate microbodies can be further divided into thirteen different types. After the characteristics of morphologies, composition and occurrence are described and analysed. This paper also discusses the microbial geneses of these microbodies, and suggests that the formation of differently-colored fillings of Zoophycos is closely related to the differences in the microbial taxa from different ecological environments, and that some kind of symbiotic relationship exists between microbes and trace-makers of Zoophycos.

\section{Acknowledgements \\ The work was jointly supported by the National Natural Science Foundation of China (Grant No. 41772104), the Basic and Frontiers Research Program of Henan Province (Grant No. 162300410256), and the Doctor Foundation of Henan \\ Polytechnic University (Grant No. B2013-075). We would also like to express our gratitude to the reviewers for their detailed revisions of our manuscript.}

Authors' contributions

All authors read and approved the final manuscript.

Competing interests

The authors declare that they have no competing interests.

\section{Publisher's Note}

Springer Nature remains neutral with regard to jurisdictional claims in published maps and institutional affiliations.

\section{Author details}

${ }^{1}$ School of Resource and Environment, Henan Polytechnic University, Jiaozuo 454000, Henan Province, China. ${ }^{2}$ Collaborative Innovation Center of Coalbed Methane and Shale Gas for Central Plains Economic Region of Henan Province, Jiaozuo 454000, Henan Province, China. ${ }^{3}$ Key Laboratory of Biogenic Traces and Sedimentary Minerals of Henan Province, Jiaozuo 454000, Henan Province, China. ${ }^{4}$ Coal Mining and Dressing Department, Changzhi Polytechnic College, Changzhi 046000, Shanxi Province, China.

Received: 11 January 2018 Accepted: 27 March 2018

Published online: 30 July 2018

\section{References}

Banfield, J.F., S.A. Welch, H. Zhang, T.T. Ebert, and R.L. Penn. 2000. Aggregation-based crystal growth and microstructure development in natural iron oxyhydroxide biomineralization products. Science 289 (5480): 751-754.

Bontognali, T.R.R., C. Vasconcelos, R.J. Warthmann, C. Dupraz, S.M. Bernasconi, and J.A. McKenzie. 2008. Microbes produce nanobacteria-like structures, avoiding cell entombment. Geology 36 (8): 663-666.

Bottjer, David J., Mary L. Droser, and David Jablonski. 1988. Palaeoenvironmental trends in the history of trace fossils. Nature 333 (6170): 252-255.

Bromley, Richard G. 1991. Zoophycos: Strip mine, refuse dump, cache or sewage farm? Lethaia 24 (4): 460-462.

Bromley, Richard G., and Nils-Martin Hanken. 2003. Structure and function of large, lobed Zoophycos, Pliocene of Rhodes, Greece. Palaeogeography, Palaeoclimatology, Palaeoecology 192: 79-100.

Burton, Sara K., and Hilary M. Lappin-Scott. 2005. Geomicrobiology, the hidden depths of the biosphere. Trends in Microbiology 13 (9): 401.

Chen, Xiao-Zheng, Wei Wang, Xin-Chun Liu, Hong-He Xu, Xiao-Lei Liu, Fan-Wei Meng, and Jin-Hui Cheng. 2007. Experimental simulation on microbial silicification. Acta Micropalaeontologica Sinica 24 (3): 261-266 (in Chinese with English abstract).

Ehrlich, Henry Lutz, and Dianne K. Newman. 2009. Geomicrobiology. 5th ed. Boca Raton: CRC Press, Taylor and Francis Group. 
Feng, Jun, Jiang-Hai Li, and Feng-You Chu. 2006. Discovery of microfossils in the seafloor black smoke from the Okinawa trough and its significance. Acta Micropalaeontologica Sinica 23 (1): 57-61 (in Chinese with English abstract).

Folk, Robert L. 2005. Nannobacteria and the formation of framboidal pyrite: Textural evidence. Journal of Earth System Science 114 (3): 369-374.

Ghiorse, W.C. 1984. Biology of iron- and manganese-depositing bacteria. Annual Review of Microbiology 38: 515-550.

Gong, Yi-Ming, Bin Hu, Zong-Sheng Lu, Yong-An Qi, and Guo-Cheng Zhang 2009. Study of trace fossils in the past eighty years in China. Acta Palaeontologica Sinica 48 (3): 322-337 (in Chinese with English abstract).

Gong, Yi-Ming, Xu Ran, Shu-Cheng Xie, Xian-Yu Huang, Hu Bin, Yong-An Qi, and Guo-Cheng Zhang. 2007. Microbial and molecular fossils from the Permian Zoophycos in South China. Science in China Series D: Earth Sciences 50 (8): $1121-1127$

Gong, Yi-Ming, Guang R. Shi, Elizabeth A. Weldon, Du Yuan-Sheng, and Xu. Ran. 2008. Pyrite framboids interpreted as microbial colonies within the Permian Zoophycos spreiten from southeastern Australia. Geological Magazine 145 (1): 95-103.

Gong, Yi-Ming, Guang R. Shi, Li-Jun Zhang, and Elizabeth A. Weldon. 2010 Zoophycos composite ichnofabrics and tiers from the Permian neritic facies in South China and South-Eastern Australia. Lethaia 43 (2): 182-196.

Hu, B., H.B. Song, S.X. Liu, and L. Zhang. 2010. Sedimentary facies, ichnofossils and storm deposits in the lower Permian Taiyuan formation, Jiaozuo city, Henan Province, Central China. Acta Geologica Polonica 60 (1): 45-52.

Juniper, S. Kim, and Yves Fouquet. 1988. Filamentous iron-silica deposits from modern and ancient hydrothermal sites. Canadian Mineralogist 26: 859-869.

Kuznetsov, S.I., M.V. Ivanov, and M.N. Lyalikova. 1963. Introduction to Geological Microbiology, translated by Xiu-yuan Wang. New York: McGraw-Hill.

Lei, Ji-Jiang, Feng-You Chu, Xiao-Hu Li, Xiao-Guo Yu, Xi-Qiu Han, Chun-Hui Tao, and Ke-Hong Yang. 2009. Discovery of microbial fossils in hydrothermal plume of the southwest Indian ridge and its significance. Acta Micropalaeontologica Sinica 26 (1): 39-47 (in Chinese with English abstract).

Ma, Heng, Fu-Chun Li, Su Ning, and Xue-Lin Li. 2009. Morphological evolution during the formation of carbonate spherulite in Citrobacter freundii culture. Geological Journal of China Universities 15 (3): 429-436 (in Chinese with English abstract).

Miller, William, III. 2003. Paleobiology of complex trace fossils. Palaeogeography, Palaeoclimatology, Palaeoecology 192: 3-14.

Miller, Molly F. 2003. Styles of behavioral complexity recorded by selected trace fossils. Palaeogeography, Palaeoclimatology, Palaeoecology 192: 33-43.

Olivero, D. 2003. Early Jurassic to late cretaceous evolution of Zoophycos in the French Subalpine Basin (southeastern France). Palaeogeography, Palaeoclimatology, Palaeoecology 192: 59-78.

Popa, Radu, Brian K. Kinkle, and Adrian Badescu. 2004. Pyrite framboids as biomarkers for iron-sulfur systems. Geomicrobiology Journal 21 (3): 193-206.

Song, Hui-Bo, Bin Hu, Zhang Lu, Shun-Xi Liu, and Yong-Bin Niu. 2011. Characteristics of lithofacies paleogeography of the Taiyuan formation sedimentary period, Henan Province. Acta Sedimentologica Sinica 29 (5): 876888 (in Chinese with English abstract).

Song, Hui-Bo, Yi Jin, Lei Hu, and Hu. Bin. 2012. Ichnofabrics and their sedimentary environment of the lower Permian Taiyuan formation, Western Henan. Acta Geologica Sinica 86 (6): 972-984 (in Chinese with English abstract).

Song, Hui-Bo, Hai-Lin Wang, Fang Wang, Rui-Rui Guo, and Hu. Bin. 2016. Ichnofossils and ichnofabrics in the lower Permian Taiyuan formation of North China Basin. Geodinamica Acta 28 (1-2): 37-52.

Southam, G., and R. Donald. 1999. A structural comparison of bacterial microfossils vs. 'nanobacteria' and nanofossils. Earth-Science Reviews 48 (4): $251-264$.

Teng, Henry, Hu Qiao-Na, Bin Lian, Jun-Feng Ji, and Jun Chen. 2006. Carbonate biomineralization induced by Bacillus megaterium. Geochimica et Cosmochimica Acta 70 (18, Supplement): A644.

Webby, B.D. 1969. Trace fossils Zoophycos and Chondrites from the tertiary of New Zealand. New Zealand Journal of Geology and Geophysics 12 (1): 208-214.

Wen, Zhi-Feng, Xian-Tai Liu, Jian-Hua Zhong, Yong Li, and Hai-Qiao Wang. 2010. Discovery of microorganism fossil and study on microorganism induced calcification in Miocene stromatolites, Qaidam Basin, China. Acta Geologica Sinica 84 (2): 263-271 (in Chinese with English abstract).

Westall, Frances, Maarten J. de Wit, Jesse Dann, Sjerry van der Gaast, Cornel E.J. de Ronde, and Dane Gerneke. 2001. Early Archean fossil bacteria and biofilms in hydrothermally-influenced sediments from the Barberton greenstone belt, South Africa. Precambrian Research 106 (1-2): 93-116.
Westall, Frances, and Robert L. Folk. 2003. Exogenous carbonaceous microstructures in early Archaean cherts and BIFs from the Isua Greenstone Belt: Implications for the search for life in ancient rocks. Precambrian Research 126 (3-4): 313-330.

Xie, Shu-Cheng, Huan Yang, Gen-Ming Luo, Xian-Yu Huang, Deng Liu, Yong-Biao Wang, Yi-Ming Gong, and Ran Xu. 2012. Geomicrobial functional groups: A window on the interaction between life and environments. Chinese Science Bulletin 57 (1): 2-19.

Xie, Shu-Cheng, Hong-Fu Yin, and Xiao-Ying Shi. 2011. Geobiology: Interactions and co-evolution between life and earth environments. Beijing: Science Press (in Chinese).

Yang, Ke-Hong, Feng-You Chu, Jian-Ru Zhao, Ji-Jiang Lei, and Yin-Xia Fang. 2009 Minerals' micro-shape and its significance of seep carbonates in the north of the South China Sea. Acta Mineralogica Sinica 29 (3): 345-352 (in Chinese with English abstract).

Zhang, Li-Jun, Dirk Knaust, and Zhao Zhao. 2016. Palaeoenvironmental and ecological interpretation of the trace fossil Rhizocorallium based on contained iron framboids (Upper Devonian, South China). Palaeogeography Palaeoclimatology Palaeoecology 446: 144-151.

Zhang, Li-Jun, G.R. Shi, and Yi-Ming Gong. 2015. An ethological interpretation of Zoophycos based on Permian records from South China and southeastern Australia. Palaios 30 (5): 408-423.

Zhang, Li-Jun, and Zhao Zhao. 2016. Complex behavioural patterns and ethological analysis of the trace fossil Zoophycos: Evidence from the lower Devonian of South China. Lethaia 49 (2): 275-284.

Zhang, Li-Wei, T. Hong, and Z. Jia. 2011. Microbialites and its significances from the lower Triassic Helongshan formation in Chaohu area, Anhui Province, South China. Scientia Geologica Sinica 46 (2): 392-403.

\section{Submit your manuscript to a SpringerOpen ${ }^{\mathcal{O}}$ journal and benefit from:}

- Convenient online submission

- Rigorous peer review

- Open access: articles freely available online

- High visibility within the field

- Retaining the copyright to your article

Submit your next manuscript at springeropen.com 